\title{
PENGEMBANGAN PERANGKAT BERCERITA UNTUK MENINGKATKAN KECERDASAN EMOSIONAL
}

\author{
oleh: Subyantoro *
}

\section{Abstrak}

Tujuan penelitian tentang bagaimanakah model bercerita berbasis analisis fungsi tokoh cerita anak-anak adalah untuk mendapatkan prototipa model bercerita dengan berbasis analisis fungsi tokoh cerita anak-anak yang dapat meningkatkan kecerdasan emosional anak usia operasional konkret melalui pendekatan penelitian dan pengembangan. Penggunaan model bercerita melalui buku panduan bercerita dan VCD bercerita ternyata memampukan anak-anak mendapatkan gambaran dan melaksanakan kegiatan bercerita yang mengarah pada pengembangan kecerdasan emosional. Keadaan yang demikian ini terlihat dari kecenderungan meningkatnya kecerdasan emosional anak-anak usia operasional konkret yang dijadikan sebagai uji coba model. Pelaksanaan pembelajaran bercerita atau pemberian cerita kepada anak akan bermakna apabila cerita yang dipilih memperhatikan aspek-aspek psikologis anak yang mencakup jenis cerita, cara bercerita, tema cerita, tokoh cerita, alur cerita, dan latar cerita; adanya penjalinan interaksi dalam proses penceritaan antara penyimak dan pencerita, dan diberikannya tindak lanjut yang bermakna bagi anak.

Kata kunci: model cerita, cerita anak-anak, kecerdasan emosional, fungsi tokoh.

\section{A. PENDAHULUAN}

Karya sastra sebagai "medan dialog" kehidupan antar tokoh-tokohnya menyajikan banyak contoh karakter kehidupan yang dapat mengembangkan aspek-aspek kecerdasan emosional. Aspek kecerdasan emosional mencakup kemampuan untuk mengenal emosi diri, kemampuan untuk mengelola dan mengekspresikan emosi, kemampuan untuk memotivasi diri, kemampuan untuk mengenali emosi orang lain, dan kemampuan untuk membina hubungan orang lain. Kelima kemampuan tersebut dapat dikembangkan melalui proses mimesis kehidupan para tokoh dalam karya sastra. Emosi anak dapat ditingkatkan dengan proses peniruan dari karakter kehidupan para tokoh yang terlihat, baik dalam alur, perwatakan, maupun dialog- dialog yang tersaji dalam karya sastra.

Berdasarkan uraian di atas rumusan masalah utama yang dikaji dalam penelitian ini adalah bagaimanakah model bercerita dengan berbasis analisis fungsi tokoh cerita anakanak, yang dapat meningkatkan kecerdasan emosional anak usia operasional konkret? Tujuan umum yang dikaji dalam penelitian tahap I ini adalah untukmem peroleh prototipe model bercerita dengan berbasis analisis fungsi tokoh cerita anak-anak, yang dapat meningkatkan kecerdasan emosional anak usia operasional konkret dalam bentuk paketpaket modul bercerita yang mengacu pada pengembangan aspek-aspek kecerdasan emosional

*) Subyantoro adalah Dosen FBS Universiras Negeri Semarang. 
Penelitian ini diharapkan memiliki kontribusi teoretis dan kontribusi praktis. Kontribusi teoretis, penelitian ini diharapkan dapat memberikan kontribusi bagi pengembangan teori psikosastra dan pengajaran sastra. Adapun kontribusi praktis yang diharapkan muncul dari penelitian ini adalah teridentifikasikannya karya-karya sastra yang digemari oleh anak dan sekaligus dapat digunakan oleh anak untuk memperkaya khasanah batin.

Dengan dekat pada karya sastra, anak-anak usia operasional konkret akan pengalaman yang konkret tentang berbagai pengalaman hidup yang disajikan pada karya sastra. Pengukuran kecerdasan emosional yang mengacu pada peristiwa hudup yang terdapat pada karya sastra akan menjanjikan kerja yang lebih efektif dan efisien. Dari segi waktu, akan terjadi penghematan karena yang ada pada karya sastra merupakan kristalisasi model kehidupan. Dari segi perkembangan kejiwaan anak, peristiwa-peristiwa kehidupan yang ada pada karya sastra sangat konkret untuk bisa dipahami oleh anak.

\section{B. TINJAUAN PUSTAKA}

\section{Hakikat Kecerdasan Emosi}

Kecerdasan emosi atau emotional intelligence merujuk pada kemampuan mengenali perasaan kita sendiri dan perasaan orang lain, kemampuan memotivasi diri sendiri, dan kemampuan mengelola emosi dengan baik pada diri sendiri, dan dalam hubungan dengan orang lain (Goleman 1999:512). Kecerdasan emosi mencakup kemampuan-kemampuan yang berbeda, tetapi saling melengkapi, dengan kecerdasan akademik (academic intellegence), yaitu kemampuankemampuan kognitif murni yang diukur dengan IQ. Banyak orang yang cerdas, dalam arti terpelajar, tetapi tidak mempunyai kecerdasan emosi, ternyata bekerja menjadi bawahan orang ber-IQ lebih rendah, tetapi unggul dalam keterampilan kecerdasan emosi.

Dua macam kecerdasan yang berbeda ini, intelektual dan emosi mengungkapkan aktivitas bagian-bagian yang berbeda dalam otak. Kecerdasan intelektual terutama didasarkan pada kerja neokorteks, lapisan yang dalam evolusi berkembang paling akhir di bagian atas otak. Adapun pusat-pusat emosi berada di bagian otak yang lebih dalam, dalam subkorteks yang secara evolusi lebih kuno; kecerdasan emosi dipengaruhi oleh kerja pusat-pusat emosi itu, tetapi dalam keselarasan dengan kerja pusat-pusat intelektual.

Di antara pakar-pakar teori tentang kecerdasan emosi paling berpengaruh yang menunjukkan perbedaan nyata antara kemampuan intelektual dan emosi adalah Howard Garner, seorang psikolog dari Harvard, yang dalam tahun 1983 memperkenalkan sebuah model yang oleh banyak orang disebut kecerdasan majemuk (multiple intelligence). Daftar tujuh macam kecerdasan yang dibuatnya meliputi tidak hanya kemampuan verbal dan matematika yang sudah lazim, tetapi juga dua kemampuan yang bersifat "pribadi"; kemampuan mengenal dunia dalam diri sendiri dan keterampilan sosial.

Sebuah teori yang komprehensif tentang kecerdasan emosi diajukan pada tahun 1990 oleh dua orang psikolog, Peter Salovey di Yale, dan John Mayer, sekarang di University of New Hampshire. Sebuah model pelopor lain untuk kecerdasan emosi diajukan dalam tahun 1980-an oleh Reuven Baron, seorang psikolog Israel. Selama beberapa tahun belakangan ini, beberapa pakar telah mengajukan teori masing-masing dengan gagasan yang kurang lebih serupa.

Salovey dan Mayer mendefinisikan kecerdasan emosi sebagai kemampuan memantau dan mengendalikan perasaan sendiri dan orang lain, serta menggunakan perasaan-perasaan itu untuk memadukan pikiran dan tindakan. Sementara para psikolog tersebut terus mempertajam teori itu, Goleman (1999) mengadaptasi model mereka ke dalam sebuah versi yang paling bermanfaat untuk memahami cara kerja bakat-bakat ini dalam kehidupan kerja. Adaptasi 
tersebut meliputi kelima dasar kecakapan emosi dan sosial sebagai berikut.

- Kesadaran diri: mengetahui apa yang kita rasakan pada suatu saat, dan menggunakan untuk memandu pengambilan keputusan diri sendiri; memiliki tolok ukur yang realistis atas kemampuan diri dan kepercayaan diri yang kuat.

- Pengaturan diri: menangani emosi kita sedemikian sehingga berdampak positif kepada pelaksanaan tugas; peka terhadap kata hati dan sanggup menunda kenikmatan sebelum tercapainya suatu sasaran; mampu pulih kembali dari tekanan emosi.

- Motivasi: menggunakan hasrat kita yang paling dalam untuk menggerakkan dan menuntun kita menuju sasaran, membantu kita mengambil inisiatif dan bertindak sangat efektif, dan untuk bertahan menghadapi kegagalan dan frustasi.

- Empati: merasakan yang dirasakan oleh orang lain, mampu memahami perspektif mereka, menumbuhkan hubungan saling percaya dan menyelaraskan diri dengan bermacam-macam orang.

- Keterampilan sosial: menangani emosi dengan baik ketika berhubungan dengan orang lain dan dengan cermat membaca situasi dan jaringan sosial; berinteraksi dengan lancar; menggunakan keterampilan ini untuk mempengaruhi dan memimpin, bermusyawarah dan menyelesaikan perselisihan, dan untuk bekerja sama dan bekerja dalam tim.

\section{Teori Naratif dalam Analisis}

\section{Sastra}

Analisis naratif berawal dari kajian di bidang linguistik sebagai modelnya dan selanjutnya berkembang sampai pada tingkat wacana (Barthes 1977:2). Perkembangan secara luas digunakan di bidang sastra. Penggunaan teori naratif berguna untuk mengungkapkan nilai kesusastraan bagi suatu karya sastra dari sudut karya sastra itu sendiri lewat pengarang kepada pembacanya. Pengkajian karya sastra semacam itu termasuk dalam kajian di bidang puitika (Rimon-Kenan 1983:2).

Penggunaan teori naratif dalam dunia sastra merupakan alat untuk membongkar karya sastra lewat struktur cerita. Struktur naratif menurut Chamamah (1991) dalam salah satu makalahnya, dikatakan bahwa struktur naratif merupakan perwujudan bentuk penyajian peristiwa yang menjadi pokok pembicara dalam wacana dengan berbagai relasi yang mengaitkan peristiwa.

Perkembangan dunia sastra khususnya yang menyangkut ilmu sastra di bidang kritik sastra ada empat pendekatan yang dapat diterapkan pada situasi karya sastra. Pendekatan itu meliputi aspek:

1. peran penulis karya sastra sebagai penciptanya (pendekatan ekspresif);

2. peran pembaca, sebagai penyambut dan penghayat (pendekatan pragmatik);

3. aspek referensial, acuan karya sastra, kaitannya dengan dunia nyata (pendekatan mimetik);

4. karya sastra sebagai struktur yang otonom, dengan koherensi intern (pendekatan objektif) (Abrams, 1981:6; lihat pula Teeuw, 1984:50-51, dan 1983: 59-60).

Menurut Piaget (dikutip oleh Chatman [1978]) bahwa konsep struktur itu ada tiga gagasan, yaikni keutuhan, transformasi, dan regulasi diri. Keutuhan yang dimaksud adalah struktur naratif itu berdiri sendiri pada tempatnya; transformasi yaitu unsur-unsur yang ada saling berhubungan dalam sebuah struktur tanpa pernah meninggalkan sistem, tetapi selalu menjadi bagian yang dimiliki sebelumnya, sedangkan regulasi diri, yaitu makna yang ada dalam struktur tersebut melingkupinya, atau struktur tersebut bermakna seluruhnya (Chatman 1978: 20-21).

Kaum strukturalis beranggapan bahwa setiap narasi itu mempunyai dua elemen. Elemen pertama berupa story (content) atau cerita yang berisi serangkaian 
peristiwa atau kejadian. Elemen kedua berupa discourse atau wacana yang berupa ekspresi atau alat-alat untuk mengungkapkan cerita (Chatman 1978:19). Struktur naratif itu merupakan penanda peristiwa atau kejadian (events), watak (charakter), dan latar (setting); dan merupakan petanda unsur-unsur yang terdapat dalam narasi (Chatman 1978: 19-25).

Barthes berpendapat bahwa terdapat tingkat-tingkat yang hierarkis pada struktur naratif dan digolongkan menjadi tiga tingkatan. Tingkatan-tingkatan tersebut adalah tingkat fungsi, tingkat aksi, dan tingkat penarasian. Dalam kenyataan sebenarnya, ketiga tingkatan itu tergabung menjadi satu, tetapi untuk penganalisisan dibuat tingkatan sedemikian rupa (Barthes 1977: 88; Sudardi 1994:13).

Sebelum dilakukan penganalisisan, perlu diadakan pembagian cerita dalam bentuk peringkat sekuen, sehingga akan dapat diketahui unit-unit naratif yang berupa sekuen inti (kernel) dan sekuen yang bukan inti (satellite).

\section{Karya Sastra sebagai Model Kehidupan dan Sarana untuk Mengembangkan Kecerdasan Emosi Anak}

Berkenaan dengan upaya meningkatkan kecerdasan emosional dapat dikakukan dengan pelibatan anak secara emosi melalui penjelajahan karya sastra. Model yang semacam inilah yang belum banyak di kaji orang melalui penelitian. Peran karya sastra sebagai salah satu sarana mengembangkan kecerdasan emosional anak, tidak terlepas dari konsep karya sastra sebagai model kehidupan. Artinya, karya sastra menggambarkan dunia imajiner yang memiliki hubungan secara langsung maupun tidak langsung dengan kehidupan dalam dunia nyata. Dalam hal ini keberadaan karya sastra yang diciptakan seorang sastrawan memang tidak dapat dilepaskan dari sastrawan dan kehidupan nyata.
Melalui karya sastra, seorang sastrawan merekam sebuah dunia kehidupan, karena ia ingin memahami kehidupan dengan membangun sebuah model dan menjelaskan berbagai kemungkinan dalam kehidupan dari model tersebut (Kayam 1998:124). Di samping itu, di dalam karya sastra ditampilkan gambaran kehidupan, dan kehidupan itu sendiri adalah suatu kenyataan sosial, yang mencakup hubungan antara manusia yang terjadi dalam dunia nyata. Dengan demikian, peristiwa-peristiwa yang terjadi dalam batin seseorang maupun dalam hubungan antar manusia, yang sering menjadi bahan sastra adalah pantulan hubungan seseorang dengan orang lain dan dengan masyarakat (Damono 1978:1).

Berangkat dari konsep tersebut, dengan membaca, menginterpretasi, dan memahami karya sastra, seseorang akan memperoleh pelajaran berharga mengenai hubungan antar manusia dengan persoalan-persoalan yang dihadapi dan pemecahannya, yang tidak bisa tidak akan melibatkan wilayah emosi, di samping intelegensi. Dengan demikian, dengan banyak membaca karya sastra, seseorang akan semakin memiliki kekayaan pengalaman yang berkaitan dengan persoalan-persoalan hidup manusia, walaupun tidak secara empiris dialaminya, yang pada gilirannya juga akan meningkatkan kecerdasan emosionalnya.

Karya sastra dalam kerangka untuk mengembangkan kecerdasan emosional anak, pertama-tama bukan dipahami sebagai unikum yang estetis ataupun struktur tanda-tanda kebahasaan yang bermakna sebagaimana dipahami oleh para ahli sastra maupun para peneliti sastra. Karya sastra dalam kerangka tersebut dimaksudkan sebagai "medan dialog " kehidupan antar tokoh-tokohnya. Bila tokoh A bicara begini, maka akan ditanggapi begitu oleh tokoh $\mathrm{B}$, dan seterusnya. Apalagi bila dialog yang terjadi tidak hanya terdiri atas dua tokoh, tetapi tiga atau bahkan lebih dari tiga 
tokoh. Bangunan stimulus-respon yang bergerak di balik dialog-dialog itu semakin baik bagi pengembangan kecerdasan emosi anak. Anak dituntut untuk menguasai banyak karakter tokoh. Oleh karena kerumitannya itu, tidak salah apabila seorang pengarang oleh Subagio Sastrawardoyo dijuluki sebagai psikolog. Karena dengan dialog-dialog yang diciptakannya itu, sebenarnya seorang pengarang telah memiliki kemampuan menguasai psikologi banyak orang. Apalagi bila tokoh-tokoh dalam karya sastra itu bicara sebagai dirinya sendiri. Itu artinya, dialog antartokoh yang terjadi bukanlah rekayasa pengarang. Akan tetapi, pengarang bersangkutan pada tingkat tertentu hanyalah menjadi media bagi tokoh-tokoh yang diciptakannya yang kemudian menjadi dirinya sendiri. Pengarang yang seperti itu memiliki tingkat kelebihan yang jauh lebih baik dari sekadar dalang. Karena bila kelebihan dalang hanya menyangkut tokoh yang berkarakter hitam putih (flat character), seorang pengarang berkaitan dengan banyak tokoh yang berkarakter bulat (round character).

Dengan menguasai pola-pola dialog berbagai hubungan stimulus-respon antartokoh dalam suatu karya sastra, seorang anak secara tidak disadari juga telah menguasai hubungan emotif antartokoh tersebut. Hubunganhubungan emotif yang samar itu, menurut Roman Ingarden, tampaknya merupakan satu jenis dari the blank (tempat-tempat terbuka yang dapat diisi oleh pembaca sesuai dengan kemampuan dan imajinasinya), yang kemudian lebih dipertajam lagi oleh Felix Vodicka maupun Wolfgang Iser dengan teori resepsi sastranya (Junus 1985:29-30). Mungkin penguasaan tersebut memang tidak bisa dijelaskan secara rasional berdasarkan kerangka logika struktural kebahasaan yang membangun karya sastra bersangkutan. Akan tetapi, mengingat selain sebagai bangunan struktur kebahasaan karya sastra juga merupakan ungkapan emosi itu sendiri, maka paling tidak penguasaan tersebut akan mengantarkan anak pada kemampuan mengelola emosinya saat bergaul dengan teman-temannya di alam nyata.

Kemampuan mengelola emosi yang dimiliki anak di alam nyata tersebut tetap merupakan trial and error. Apalagi bila diingat bahwa kehidupan nyata itu memiliki tingkat kompleksitas persoalan yang lebih rumit bila dibandingkan dengan suatu peristiwa dalam sebuah karya sastra.

Meskipun demikian, dialog-dialog dalam sebuah karya sastra sebagai suatu konstruksi model tentang hubungan antar manusia di alam nyata, paling tidak juga merupakan refleksi psikologis pengarang atas kehidupan nyata sehari-hari yang dihadapinya dan kemudian secara tidak disadari menarik dirinya untuk lebih jauh mendeskripsikannya dalam sebuah karya sastra.

Pengajaran sastra untuk mencapai tingkat kecerdasan emosional sebagaimana diuraikan di atas memang sulit diukur dengan angka-angka. Pencapaian kemampuan mengelola emosi pada seorang anak sangat dipengaruhi oleh kepribadian anak ketika bergaul di alam nyata. Hanya saja, sebagai langkah pengajaran, sastra yang menurut Plato (dalam Teeuw 1984:219) merupakan mimesis (tiruan) kenyataan paling tidak dapat mengantarkan anak memasuki kenyataan hidup itu sendiri.

Dari uraian di atas jelas kiranya keterkaitan antara pengembangan kecerdasan emosional dan penjelajahan dialog antartokoh dalam karya sastra. Setidaknya melalui penelitian ini akan ditemukan model yang dapat memperkaya pengalaman anak dari contoh-contoh model kehidupan para tokoh yang ada dalam karya sastra. Anak tidak perlu belajar dan berlatih untuk kecerdasan emosional dari kehidupan nyata yang memerlukan sejumlah waktu untuk mendapatkannya. Karya sastra sebagai contoh baik kristal kehidupan 
masyarakat dapat menjadi sarana pengembangan kecerdasan emosional yang efektif dan efisien bagi anak.

\section{METODE PENELITIAN}

Subjek penelitian ini adalah pemahaman karakter tokoh yang ada pada karya sastra (adalam hal ini cerita) pada anak-anak sekolah usia operasional konkret dan kecerdasan emosional mereka. Anak usia operasional konkret yang digunakan sebagai sumber data penelitian ini adalah siswa SD kelas IV di Kota Semarang tahun 2003. Dalam penelitian ini, instrumen yang digunakan meliputi: lembar observasi, angket, pedoman wawancara, dan inventory. Adapun teknik pengumpulan data melalui observasi, wawancara, dan tes.

Data penelitian ini diperoleh dengan trianggulasi metode dan situasi. Trianggulasi metode dilakukan dengan cara crossing data dari hasil observasi, wawancara, dan tes. Adapun trianggulasi situasi dengan cara membandingkan data situasi yang diperoleh dari proses dialog yang dilakukan anak, baik secara sendiri (internalisasi nilai) maupun secara bersama atas nilai-nilai kehidupan yang berhasil ditangkap mereka setelah disajikannya cerita.

\section{HASIL PENELITIAN DAN PEMBAHASANNYA}

Buku panduan bercerita dan VCD bercerita, sebagai hasil penelitian ini, disusun untuk memberikan fasilitas tuntunan kepada guru atau para orangtua apabila ingin bercerita dengan anaknya, jadi bukan untuk anak secara langsung. Berdasarkan hasil penelitian, buku cerita dan VCD yang telah diproduksi mendapatkan banyak masukan untuk penyempurnaan, baik yang berasal dari ahli pembelajaran bercerita maupun dari guru.

Untuk buku panduan bercerita, ahli pembelajaran bercerita memberikan masukan pada 9 aspek, yaitu: (1) komposisi warna halaman judul, (2) tampilan gambar halaman judul, (3) tampilan tulisan halaman judul, (4) uraian isi pada prakata, (5) uraian awal pada paket cerita, (6) ringkasan pada paket cerita, (7) contoh dialog pada ringkasan cerita, (8) gambar ilustrasi cerita dapat membantu memahami isi cerita, (9) kemampuan kalimat tuntunan menjadi sarana penunjang pengembangan kecerdasan emosional. Adapun masukan dari guru untuk perbaikan buku panduan bercerita mencakup 7 aspek, yaitu: (1) komposisi warna halaman judul, (2) tampilan gambar halaman judul, (3) uraian isi pada prakata, (4) uraian awal pada paket cerita, (5) contoh dialog pada ringkasan cerita, (6) gambar ilustrasi cerita dapat membantu memahami isi cerita, dan (7) kemampuan kalimat tuntunan menjadi sarana penunjang pengembangan kecerdasan emosional.

Masukan dari ahli pembelajaran bercerita dan guru, 7 aspek di antaranya memiliki kesamaan, sedangkan 2 aspek yang lain berbeda. Kedua aspek tersebut adalah tampilan tulisan halaman judul dan ringkasan pada paket cerita. Secara garis besar, masukan keduanya memiliki kesamaan, yaitu menginginkan buku panduan bercerita yang menarik dari segi sampul dan berkualitas dari segi isinya.

Masukan yang diberikan oleh ahli pembelajaran bercerita dan guru, masingmasing 10 aspek masukan dari ahli pembelajaran dan 7 aspek masukan dari guru. Kesepuluh masukan dari ahli pembelajaran bercerita tersebut adalah (1) komposisi warna perwajahan kotak VCD, (2) tampilan gambar perwajahan kotak VCD, (3) tampilan tulisan perwajahan VCD, (4) apersepsi yang diberikan pencerita saat mulai bercerita, (5) penjalinan kedekatan pencerita dengan pendengar, (6) dialog antara pencerita dan pendengar, (7) pemberian penekanan pencerita untuk meningkatkan kecerdasan emosional, (8) selipan humor saat bercerita, (9) simulasi emosi selama proses penceritaan, dan (10) kesesuaian waktu dengan daya konsentrasi anak.

Adapun ke-7 masukan dari guru adalah (1) komposisi warna perwajahan kotak VCD, (2) tampilan gambar perwajahan kotak VCD, (3) apersepsi yang diberikan pencerita saat mulai bercerita, (4) penjalinan kedekatan pencerita 
dengan pendengar, (5) dialog antara pencerita dan pendengar, (6) selipan humor saat bercerita, dan (7) simulasi emosi selama proses penceritaan.

Perbedaan masukan keduanya terletak pada aspek tampilan tulisan perwajahan VCD, pemberian penekanan pencerita untuk meningkatkan kecerdasan emosional, dan kesesuaian waktu dengan daya konsentrasi anak.

Secara umum kedua masukan untuk perbaikan VCD bercerita adalah keduanya menginginkan tampilan fisik VCD bercerita yang menarik dan tampilan pencerita yang komunikatif, dekat, hangat dengan pendengar sehingga mampu mentransfer aktivitas emosi tokoh yang ada pada cerita. Kondisi tersebut memungkinkan pencerita mampu mengajak pendengar untuk mengembangkan kecerdasan emosinya.

Kondisi seperti di atas memungkinkan kegiatan bercerita menjadi kegiatan yang menyenangkan. Bercerita yang baik memiliki kekuatan yang spesifik untuk mengaktifkan otak emosional yang bisa mengkondisikan saraf otak bekerja secara rileks dan mediatif. Inilah kekuatan penting bercerita dalam meningkatkan kecerdasan emosional anak. Saat anak mendengarkan cerita, saraf otak mereka bekerja dalam gelombang alpha, sehingga saraf otak berada dalam kondisi rileks dan bisa berdansa untuk saling bertemu dengan serabut sel yang lain secara bergantian. Pertemuan secara bergantian inilah yang disebut oleh Mukejerea (1998:15) sebagai brain dancing yang menghasilkan pikiran-pikiran kreatif inovatif dan penuh kasih sayang.

Terciptanya brain dancing inilah yang memungkinkan kecerdasan emosional anak akan dapat ditingkatkan, sebagaimana pengukuran kecerdasan emosional setelah anak-anak mendengarkan 10 kali cerita. Perbandingan peningkatan kecerdasan emosional anak usia operasional konkret yang dijadikan subjek penelitian ini sebagai berikut.
Tabel 1.

Pengembangan Kecerdasan Emosional Melalui Analisis Fungsi Tokoh pada Cerita

\begin{tabular}{|l|c|c|c|c|}
\hline \multirow{2}{*}{ Interval } & \multicolumn{2}{|c|}{ frekuensi } & \multicolumn{2}{c|}{ Persentase (\%) } \\
\cline { 2 - 5 } & sebelum & setelah & sebelum & Setelah \\
\hline $0-20$ & 0 & 0 & $0 \%$ & $0 \%$ \\
\hline $21-40$ & 7 & 6 & $14 \%$ & $11 \%$ \\
\hline $41-60$ & 39 & 20 & $74 \%$ & $38 \%$ \\
\hline $61-80$ & 6 & 26 & $12 \%$ & $51 \%$ \\
\hline & 52 & 52 & $100 \%$ & $100 \%$ \\
\hline
\end{tabular}

Berdasarkan data pada Tabel 1. terlihat bahwa kecerdasan emosional melalui analisis fungsi tokoh cerita pada anak usia operasional konkret, menunjukkan kecerdasan emosionalnya perlu pengembangan lebih lanjut, sebelum penceritaan sebanyak $14 \%$, setelah penceritaan mengalami penurunan menjadi $11 \%$; kecerdasan emosional telah berkembang dengan baik, sebelum penceritaan sebanyak $74 \%$, setelah penceritaan mengalami penurunan menjadi $38 \%$; dan kecerdasan emosional yang tinggi, sebelum cerita sebanyak $12 \%$, sedangkan setelah pengukuran mengalami peningkatan menjadi 51\%.

\section{E. SIMPULAN DAN SARAN}

\section{Simpulan}

Berdasarkan hasil penelitian dapat diberikan simpulan sebagai berikut.

- Untuk buku panduan bercerita, ahli pembelajaran bercerita memberikan masukan pada 9 aspek, yaitu: (1) komposisi warna halaman judul, (2) tampilan gambar halaman judul, (3) tampilan tulisan halaman judul, (4) uraian isi pada prakata, (5) uraian awal pada paket cerita, (6) ringkasan pada paket cerita, (7) contoh dialog pada ringkasan cerita, (8) gambar ilustrasi cerita dapat membantu memahami isi cerita, (9) kemampuan kalimat tuntunan menjadi sarana penunjang pengembangan kecerdasan emosional. Adapun 
masukan dari guru untuk perbaikan buku panduan bercerita mencakup 7 aspek, yaitu: (1) komposisi warna halaman judul, (2) tampilan gambar halaman judul, (3) uraian isi pada prakata, (4) uraian awal pada paket cerita, (5) contoh dialog pada ringkasan cerita, (6) gambar ilustrasi cerita dapat membantu memahami isi cerita, dan (7) kemampuan kalimat tuntunan menjadi sarana penunjang pengembangan kecerdasan emosional.

- Masukan yang diberikan oleh ahli pembelajaran bercerita dan guru, untuk perbaikan VCD bercerita masing-masing 10 aspek masukan dari ahli pembelajaran dan 7 aspek masukan dari guru. Kesepuluh masukan dari ahli pembelajaran bercerita tersebut adalah (1) komposisi warna perwajahan kotak VCD, (2) tampilan gambar perwajahan kotak VCD, (3) tampilan tulisan perwajahan VCD, (4) apersepsi yang diberikan pencerita saat mulai bercerita, (5) penjalinan kedekatan pencerita dengan pendengar, (6) dialog antara pencerita dan pendengar, (7) pemberian penekanan pencerita untuk meningkatkan kecerdasan emosional, (8) selipan humor saat bercerita, (9) simulasi emosi selama proses penceritaan, dan (10) kesesuaian waktu dengan daya konsentrasi anak.Adapun ke-7 masukan dari guru adalah (1) komposisi warna perwajahan kotak VCD, (2) tampilan gambar perwajahan kotak VCD, (3) apersepsi yang diberikan pencerita saat mulai bercerita, (4) penjalinan kedekatan pencerita dengan pendengar, (5) dialog antara pencerita dan pendengar, (6) selipan humor saat bercerita, dan (7) simulasi emosi selama proses penceritaan.

- Pemberian cerita yang berbasis analisis fungsi tokoh cerita dapat meningkatkan kecerdasan emosional pada anak usia operasional konkret. Peningkatan tersebut adalah kecerdasan emosionalnya perlu pengembangan lebih lanjut, sebelum penceritaan sebanyak 14\%, setelah penceritaan mengalami penurunan menjadi 11\%; kecerdasan emosional telah berkembang dengan baik, sebelum penceritaan sebanyak $74 \%$, setelah penceritaan mengalami penurunan menjadi 38\%; dan kecerdasan emosional yang tinggi, sebelum cerita sebanyak $12 \%$, sedangkan setelah pengukuran mengalami peningkatan menjadi $51 \%$.

\section{Saran}

Berdasarkan simpulan penelitian dapatlah diberikan saran sebagai berikut.

- Pelaksanaan pembelajaran bercerita atau pemberian cerita kepada anakanak akan bermakna apabila cerita yang dipilih memperhatikan aspekaspek psikologis anak, yang mencakup jenis cerita, cara bercerita, tema cerita, tokoh cerita, alur cerita, dan latar cerita; adanya penjalinan interaksi dalam proses penceritaan antara penyimak dan pencerita, dan diberikannya tindak lanjut yang bermakna bagi anak.

- Perlu pemberian cerita untuk meningkatkan kecerdasan emosional anak karena bercerita yang baik memiliki kekuatan yang spesifik untuk mengaktifkan otak emosional yang bisa mengkondisikan saraf otak bekerja secara rileks dan mediatif. Inilah kekuatan penting bercerita dalam meningkatkan kecerdasan emosional anak. Saat anak mendengarkan cerita, saraf otak mereka bekerja dalam gelombang alpha, sehingga saraf otak berada dalam kondisi rileks dan bisa berdansa untuk saling bertemu dengan serabut sel yang lain secara bergantian. 


\section{DAFTAR PUSTAKA}

Abram, M.H. 1981. The Mirror and the Lamp: Romantic Theory and Critical Tradition: London: Oxford University Press.

Barthes, Roland. 1977. Image Music Text. Diterjemahkan oleh Stephen Heath. New York: Hill and Wang.

Chamamah-Soeratno, Siti. 1991. "Teori Naratif". Makalah Penataran Sastra (tidak diterbitkan). Yogyakarta.

Damono, Sapardi Djoko. 1978. Sosiologi sastra: Sebuah Pengantar. Jakarta: Pusat Pembinaan dan Pengambangan Bahasa.

Elias, M.J. and R.P. Weisberg. 1990. "SchoolBased Social Competence Promotion as a primary Prevention Strategy: A Tale of Two Projects," Journal Prevention in Human Services 7, 1, pp 177-200.

Goleman, Daniel. 1999. Emotional Intellegence. Alih Bahasa: T. Hermaya. Jakarta: Gramedia.

Hawkins, J.D. et al. 1991. "Reducing Early Childhood Aggression: Results of a Primary Prevention Program," Journal of the American Academy of Child and Adolesence Psychiatry 30, 2 (1991), pp 208-17.

Junus, Umar. 1985. Resepsi Sastra: Sebuah Pengantar. Jakarta: Gramedia.

Kayam, Umar. 1988. "Memahami Roman
Indonesia Modern sebagai Pencerminan dan Ekspresi Masyarakat dan Budaya Indonesia Suatu Refleksi," dalam Mursal Esten, ed., Menjelang Teori dan Kritik Susastra Indonesia yang Relevan. Bandung: Angkasa.

Pertiwi, Aprilia Fajar. 1997. Mengembangkan Kecerdasan Emosi Anak. Jakarta: Yayasan Aspirasi Pemuda.

Rimmon-Kenan, Shlomith. 1983. Narrative Fiction: Contemporary Poetics. London: Metheun and Co. Ltd.

Schaps, E. and V. Battistich. 1991. "Promoting Heelth Development Through School-Based Prevention: New Approaches," OSAP Prevention Mpnograph, no 8: Preventing Adolescent Drug Use: Form Theory to Practice.

Shapiro, E. Lawrence. 1995. How to Raise A Child With a Hight EQ: A Parents' Guide to Emotional Intelligence. New York: Harper Collins Publishers, Inc.

Sudardi, Bani. 1994. "Struktur Naratif Hikayat Mahsyud Hak". Tesis S2. Yogyakarta: Fakultas Pascasarjana-UGM.

Teew, A. 1983. Membaca dan Menilai Sastra. Jakarta: Gramedia. 1984. Sastra dan IImu Sastra: Pengantar IImu Sastra. Jakarta: Pustaka Jaya-Girimukti Pustaka. 